\title{
Modes of entry to male immigrant entrepreneurship in a rural context: Start-up stories from Northern Norway
}

\author{
Mai Camilla Munkejord
}

\begin{abstract}
A B S T R A C T
Objective: The purpose of this article is to address rural and gender gaps in the immigrant entrepreneurship literature by analysing the start-up narratives of nine male entrepreneurs in Finnmark in northernmost Norway.

Research Design \& Methods: The article is based on a qualitative fieldwork including business visits and in-depth interviews. The transcripts from the interviews were analysed using a constructivist grounded theory approach (CGT).

Findings: The article contributes to the entrepreneurship and to the immigrant entrepreneurship literature by highlighting the gendered experiences of male immigrant entrepreneurs, by identifying three distinct modes of entry into rural immigrant entrepreneurship and by revealing how the experiences of entrepreneurs are shaped by the family and spatial contexts.

Implications \& Recommendations: This study notes that the modes of entry to rural immigrant entrepreneurship are diverse, but often related to the pursuit of an initial feeling of belonging in the new region of settlement. Hence, developing our knowledge of how to not only attract but also retain and increase the feeling of local belonging of immigrants may be important for many rural regions in the Western world.
\end{abstract}

Contribution \& Value Added:The originality of this article is to address rural and gender gaps in the immigrant entrepreneurship literature by analysing the start-up narratives of nine male entrepreneurs in Finnmark in northernmost Norway.

\section{Article type: research paper \\ Keywords: male immigrant entrepreneurship; rural context; spatial and family embeddedness; modes of entry; gender}

JEL codes: $\quad$ C33, F21

Received: 30 May 2015

Revised: 10 September 2015 Accepted: 15 September 2015

\section{Suggested citation:}

Munkejord, M.C. (2015). Modes of entry to male immigrant entrepreneurship in a rural context: Start-up stories from Northern Norway. Entrepreneurial Business and Economics Review, 3(3), $143-$ 160. doi: 10.15678/EBER.2015.030308 


\section{INTRODUCTION}

An increasing number of immigrant men are starting businesses in rural areas of the Western world, primarily because of the recent growth in rural immigration (Danson \& Jentch, 2009; de Lima \& Wright, 2009; Simard \& Jentch, 2009). But, what are the stories of immigrant male entrepreneurs in rural areas? What makes them start a business, and what shapes their experiences? While immigrant entrepreneurship (IE) has been developed into a significant field of study (Aldrich \& Waldinger, 1990; Almor \& Yeheskel, 2013; Crockett, 2013; Evans, 2012; Kloosterman \& Rath, 2001; Portes \& Zhou, 1996; Ram \& Jones, 2008; Stephens, 2013; Turkina \& Thai, 2013), it can be criticised for having neglected rural contexts and for overlooking gender in the analysis. Also, in cases where gender is addressed, female participants are automatically scrutinised, as if the experiences and practices of male entrepreneurs were not gendered.

This article addresses rural and gender gaps in the immigrant entrepreneurship literature by analysing the stories of nine male immigrants who currently operate a business in Finnmark in northernmost Norway. Different theoretical frameworks are suggested in the literature to conceptualise the processes related to how different actors choose selfemployment. One example is the '5M framework' (Brush, de Bruin \& Welter 2009), which was originally developed to understand female entrepreneurship but, I would argue, is equally relevant to highlighting men's experiences, immigrant or not. In addition to market, money and management, the $5 \mathrm{M}$ framework highlights the significance of 'motherhood' and the 'meso/macro environment'. Whereas the motherhood metaphor refers to the household or family context and implies recognition of the fact that entrepreneurial processes are interconnected to gender and household dynamics, the meso/macro environment includes considerations outside of the market, such as cultural norms and policies, legislation, and the spatial context.

This article aims to enhance our understanding of the immigrant entrepreneurial start-up phase. In particular, the following questions are explored: Why did the participants choose to become self-employed? How does the family contribute to shaping the entrepreneurial business start-ups among the participants in this study? And in what ways are the businesses embedded in the local rural context in which the participants live?

The article contributes to the entrepreneurship literature in general and to the immigrant entrepreneurship literature in particular in three ways: first, by highlighting the gendered experiences of male immigrant entrepreneurs; second, by identifying three distinct modes of entry into rural immigrant entrepreneurship, including a) entrepreneurship as a means to live in a region of perceived attractiveness; b) entrepreneurship 'because I was asked to do it' and c) entrepreneurship as a preferred choice for men in satisfactory wage labour; and third, by revealing that the experiences of participants, regardless of their mode of entry into entrepreneurship, are shaped by the family and the spatial context within which the entrepreneur is situated.

This article is organised in the following manner: I will begin by introducing the geographical context for this study. I will then present the conceptual and methodological framework before demonstrating the analysis of the empirical data. In the final section, I will present conclusions, limitations and ideas for future research. 


\section{Context}

Finnmark County is located in Norway in northernmost Europe. However, as a result of the Gulf Stream, the climate is relatively mild. Finnmark's surface is 48637 square kilometres but, despite its size, the region has only 75000 inhabitants ${ }^{1}$ and has suffered for decades from a steady population decline. Since 2007, however, population rates have stabilised and increased slightly, primarily because of immigration. The total number of immigrants living in Finnmark in 2012 was 6773, constituting 9.2\% of the total population (Special table, Statistics Norway).This is a little below the national average of $11 \%$. In terms of numbers, the immigrants in Finnmark originate primarily from Russia and Finland; secondly from Poland, Lithuania and Sweden; and thirdly from Thailand, Afghanistan and Somalia.

Finnmark stretches between 70 and 71 degrees north. This far north, winters are dark and the sun is below the horizon for two months. During summertime, however, the midnight sun brings light to inhabitants and attracts tourists to the region. The landscape is open and stony with wild mountains, vast plateaus and naked shores surrounded by the sea. Because of the Gulf Stream, the climate is relatively mild compared with other places at similar altitudes. Trees are rare in parts of the county, but there is a great deal of green grass, small bushes and heather moors. Finnmark has a long coastline and the majority of the population lives relatively clustered along the coast in fishing villages and small towns. Fisheries have long played a crucial role (Gerrard, 2005, 2013), previously in combination with small-scale peasant farming. More recently, other sectors have become more important, such as fish farming, small-scale nature-based tourism and different types of skilled employment in the public welfare sector as well as in industrial mega-projects based on the extraction of natural resources. The self-employment rates in Finnmark are relatively low at approximately $4 \%$. Because of the increased international in-migration, however, the number of immigrant firms is currently increasing, and according to special tables from Statistics Norway, there were approximately $170 \mathrm{immi}-$ grant entrepreneurs in Finnmark in 2010, constituting 3.2\% of the immigrant population aged 18-65 (Special table, Statistics Norway).

\section{LITERATURE REVIEW}

\section{From Culturalist via Structuralist Explanations ...}

As it is common in the literature, I define entrepreneurship as the creation of new ventures, and entrepreneurs as venture creators (Gartner, 1988). Hence, immigrant entrepreneurs are venture creators who have migrated to Norway. Two models have predominated in the literature theorising the phenomenon of immigrant business start-ups: 1) a model arguing that certain immigrant groups have a particular cultural inclination towards entrepreneurship (Aldrich \& Waldinger, 1990; Basu \& Altinay, 2002; Fairlie \& Meyer, 1996; Mora \& Dávila, 2005; Teixeira, 1998) and 2) a model emphasising the structural constraints and opportunities available to immigrants in the hosting context (Lee,

\footnotetext{
${ }^{1}$ In 2013, Statistics Norway: http://www.ssb.no/befolkning/statistikker/folkendrkv/kvartal/2014-02-20?fane= tabell\&sort=nummer \&tabell=164147
} 
1999; Phizacklea \& Ram, 1996; Shinnar \& Young, 2008; Waldinger, 1994). The first model often uses ethnicity in a uniform and stereotypical manner that assigns common characteristics to different people. Thus, as argued by Collins and Low (2010, p. 101), 'in some cultural explanations, immigrant entrepreneurship is simply reduced to the supposed innate "entrepreneurial bent" of certain ethnic groups (often Chinese, Italian or Jewish)'. The problem with such a perspective is apparent: any 'immigrant group' or 'ethnic minority' consists of a large number of people with different social and human capital and with various migration backgrounds, and their experiences related to, e.g., starting and developing a business should hence not be analysed under a common umbrella that ignores variations within the group. The second model relates to constraints and opportunities and in particular considers how immigrants are pushed or pulled into selfemployment. The push factors refer to processes of discrimination. Within this line of argument, immigrant self-employment is commonly understood as the absence of other opportunities (often referred to as the disadvantage hypothesis). The pull factors, on the other hand, refer to market conditions in the host context. This perspective hence suggests that immigrants are pulled into entrepreneurship because of the structure of the host economy using explanatory terms such as 'enclave economy', 'ethnic niches' and 'occupational niches'. For an elaboration of these structural perspectives, see Brettell and Alstatt (2007).

Although both cultural and structural factors are significant for understanding why and how immigrants choose self-employment, the above-mentioned models are not sufficiently developed to grasp agency in terms of individual interests and aspirations, as argued by several academics (Brettell \& Alstatt, 2007; Essers, Benschop, \& Dooreward, 2010; Khosravi, 1999). Moreover, the models are shaped within a mega-city context and are therefore not necessarily relevant to explaining immigrant entrepreneurship in a Western rural setting, as this article will illustrate. Furthermore, these models are also developed without adequate theorising of the gender and family embeddedness of entrepreneurial processes (Collins \& Low, 2010).

\section{... to the 5M Framework Highlighting the Family and Spatial Contexts}

Thus, different frameworks are suggested in the literature to better conceptualise the processes related to how different agents choose self-employment, whether they are immigrants or not. In this article, I draw on the ' $5 \mathrm{M}$ framework' (Brush, de Bruin and Welter 2009) that I briefly presented in the introduction. The $5 \mathrm{M}$ framework extends the existing $3 \mathrm{M}$ framework (Bates, Jackson, \& Johnson, 2007) implying that an entrepreneur seeking to start and develop a business needs access to the market, money and management, the latter in the sense of human capital (Bates, Jackson, \& Johnson, 2007, p. 9). In the 5M framework, 'motherhood' and the 'meso/macro environment' are added, the motherhood metaphor implying that entrepreneurial processes are interrelated with gender and family dynamics and the meso/macro environment emphasizing the significance of considerations outside of the market. These meso/macro considerations include cultural norms and policies, legislation and the spatial context related to urbanity and rurality in terms of geographical localization, population density and the dynamics of the local labour market that may also influence entrepreneurial motivations, access to resources and realization of business ideas. 


\section{From the Entrepreneur as a Masculine Individualist to the Entrepreneur as a Family Member}

Based on a social constructivist approach, gender in this article is perceived as a relationship between masculinity and femininity viewed as cultural understandings regarding male and female bodies related to expectations of gendered differences in interests, activities, preferences, values, choices of education and career, etc. Several feminist scholars have analysed how the concepts of masculinity and entrepreneurship are intertwined (Ahl, 2004, 2006; Bruni, Gherardi, \& Poggio, 2004; Essers et al., 2010; Jennings \& Brush, 2013), indicating that entrepreneurship is constructed as a masculine activity associated with innovation and growth, whereas the entrepreneur is constructed as a courageous, daring, self-centred, power seeking, active and independent man (Ahl 2004, pp. 51-54). However, research that has compared female and male entrepreneurs on personal characteristics has shown that both sexes reflect the entrepreneurial norm to the same extent, in other words: men do not necessarily score higher on the so-called 'entrepreneurship attributes'. In other words, the achieving and individualistic male entrepreneur is a particular cultural construct of masculinity (Ahl 2004, 2006). Contrary to constructions of the entrepreneur as an independent power-seeking individualist, recent scholarship rather indicates that many entrepreneurial decisions are collective processes influenced by the family of the entrepreneur (Aldrich \& Cliff, 2003; Alsos, Carter, \& Ljunggren, 2014; Jennings, Breitkreuz, \& James, 2013; Jennings \& Brush, 2013; Jennings \& McDougald, 2007; Rogoff \& Heck, 2003). In particular, the literature indicates that entrepreneurs may rely on different types of moral and instrumental support from spouses and other family members to assist them in realising their business plans (Eddleston \& Powell, 2012). In this article, I will analyse male immigrant entrepreneurs' accounts of the start-up phase with a particular focus on how they relate to the hegemonic discourse on the entrepreneur as an independent and power-seeking man versus recent research that reveals the significance of the entrepreneur as embedded in his or her family.

\section{MATERIAL AND METHODS}

This article explores the motivations for starting a business among immigrant men in Finnmark, located in the north of Norway. Given the scarcity of knowledge about this theme and to obtain a thorough description of the participants' own understanding of their experiences, a qualitative, interpretative approach was thought to be the most appropriate (Bagwell, 2008; Haavind, 1999; Shaw, 2006; Søndergaard, 1999, 2002). Narratives are often used within interpretative methodology to explore how individuals comprehend their everyday life situations. This methodology is suitable because telling their stories enables individuals to draw on memory and current experience and hence to bridge the past and the present (Cullum, 2003; Terjesen \& Elam, 2009).

The fieldwork was conducted in 2012, including business visits and semi-structured in-depth interviews with nine immigrant men and twenty immigrant women who had started their own businesses and hence were self-employed. I used personal networks and the snowball method to identify potential informants who were purposefully selected on the basis of their migration background, education, family situation and business 
sector. All participants gave their informed consent ${ }^{2}$. The stories of the nine male entrepreneurs selected for the purpose of this particular article on male immigrant entrepreneurs concerned running nine businesses: four male-led, four couple-led (three of these co-ethnic wives were also interviewed) and one team-led (an immigrant with a Norwegian partner, both interviewed). One of the businesses was run from home, whereas eight businesses had separate workplaces. There was some variation among the businesses related to their size, income provision and the hours that entrepreneurs work. The businesses were varied and included fast-food restaurants, a garage, an architectural firm, a nature-based tourism business and firms providing massage therapy and acupuncture.

Most of the interviews took place at the participants' workplaces, whereas a couple of them preferred to be interviewed at home or in a café. The interviews were conducted in Norwegian with some use of English, as all participants were quite fluent in the Norwegian language and, when needed, also had supplementary knowledge of English. The key topics in the interviews were 1 ) their backgrounds in terms of childhood, education, previous work experience, their stories about migrating to Finnmark and their new everyday lives in the north as well as 2) their experiences as entrepreneurs, including their reasons for starting a business, networking practices, the role of their family in starting and running the business and future plans. The interviews were tape recorded and lasted from 35 to 130 minutes, with an average duration of 75-80 minutes. The transcripts were thematically analysed using the constructivist grounded theory approach (CGT) (Charmaz, 2005, 2006, 2009). The CGT approach implies, e.g., that the researcher takes a reflexive stance in terms of searching for multiple perspectives by analysing the empirical data using general rather than specific concepts (Charmaz, 2005, p. 509). After a preliminary thematic analysis of the empirical data from the interviews, I chose theories on immigrant entrepreneurship, family embeddedness and spatial embeddedness as a sensitising framework that allowed for further analysis of the participants' accounts of their experiences with starting a business in the rural north. The analysis was assisted by the use of NVIVO-10 to manage and code the material and to support the transparency of the analysis. Quotations have been translated into English for the purpose of this article. All names in this article are fictitious for the sake of confidentiality.

Background information about the participants. Five of the participants had a background as refugees from Asia and Africa. These individuals were sent to the West by their families to try to make a new start and thereafter to help their relatives left behind. The other four participants can be categorised as lifestyle migrants (O'Reilly \& Benson, 2009). These participants came from Western Europe and from Russia and had settled in northernmost Norway for slightly different reasons, but all of them shared that they were attracted to the Arctic and that they wanted to experience something 'different' and 'exotic'. As indicated in the table below, the educational level was not the same between the two groups of immigrants: three of the refugees had no education beyond primary school, and two of them had secondary education (craftsman certificates and a massage certificate), whereas all of the lifestyle migrants had university degrees.

\footnotetext{
${ }^{2}$ They were informed about their rights to refuse participation and to withdraw their statements at any time. In addition, the research project was approved by Norwegian Social Science Data Services.
} 
Table 1. Overview of the participants

\begin{tabular}{|c|c|c|c|c|c|c|}
\hline $\begin{array}{l}\text { Name and age } \\
\text { (approx) }\end{array}$ & $\begin{array}{l}\text { Migration background } \\
\text { + region of origin }\end{array}$ & $\begin{array}{l}\text { Trade, year of } \\
\text { start-up }\end{array}$ & $\begin{array}{l}\text { Marital } \\
\text { status }\end{array}$ & $\begin{array}{l}\text { How the business } \\
\text { is led }\end{array}$ & Education & $\begin{array}{c}\text { Family } \\
\text { dependents }\end{array}$ \\
\hline Ali, 30 & Refugee, Asia & Restaurant (2007) & $\begin{array}{c}\text { Spouse from } \\
\text { his country }\end{array}$ & Male-led & Primary & - \\
\hline Julius, 45 & Refugee, Asia & $\begin{array}{l}\text { Massage } \\
\text { treatment (2003) }\end{array}$ & $\begin{array}{l}\text { Spouse from } \\
\text { his country }\end{array}$ & Male-led & Massage education in Norway & $\begin{array}{c}\text { Three children, } \\
\text { kindergarten and } \\
\text { school age }\end{array}$ \\
\hline Paul, 45 & Refugee, Africa & $\begin{array}{c}\text { Retail store (2006) } \\
\text { \& café (2012) }\end{array}$ & $\begin{array}{l}\text { Spouse from } \\
\text { his country }\end{array}$ & Couple-led & Primary & $\begin{array}{l}\text { Four children, school } \\
\text { age }\end{array}$ \\
\hline Mehmet, 35 & Refugee, Asia & Garage (2010) & $\begin{array}{c}\text { Spouse from } \\
\text { Norway }\end{array}$ & $\begin{array}{c}\text { Team-led (with a } \\
\text { Norwegian partner) }\end{array}$ & $\begin{array}{c}\text { Craftsman certificate from both } \\
\text { country of origin and Norway }\end{array}$ & One child (baby) \\
\hline Ahmed, 35 & Refugee, Asia & Restaurant (2005) & $\begin{array}{c}\text { Spouse from } \\
\text { his country }\end{array}$ & Couple-led & Primary & One child (baby) \\
\hline Erik, 35 & $\begin{array}{l}\text { Lifestyle migrant, } \\
\text { Western Europe }\end{array}$ & $\begin{array}{c}\text { Architectural firm } \\
(2008)\end{array}$ & $\begin{array}{c}\text { Spouse from } \\
\text { his country }\end{array}$ & Couple-led & Univ. degree & $\begin{array}{l}\text { Two children } \\
\text { (kindergarten) }\end{array}$ \\
\hline Vladimir, 40 & $\begin{array}{l}\text { Lifestyle migrant, } \\
\text { Russia }\end{array}$ & $\begin{array}{l}\text { Tourism firm } \\
\text { (2012) }\end{array}$ & $\begin{array}{l}\text { Spouse from } \\
\text { his country }\end{array}$ & Male-led & Univ. degree & $\begin{array}{c}\text { Two children } \\
\text { (kindergarten and } \\
\text { school age) }\end{array}$ \\
\hline Lars, 45 & $\begin{array}{l}\text { Lifestyle migrant, } \\
\text { Western Europe }\end{array}$ & $\begin{array}{c}\text { Massage and } \\
\text { acupuncture } \\
\text { treatment (2002) }\end{array}$ & $\begin{array}{l}\text { Spouse from } \\
\text { his country }\end{array}$ & Male-led & Univ. degree & $\begin{array}{c}\text { Three children } \\
\text { (kindergarten and } \\
\text { school age) }\end{array}$ \\
\hline Jürgen, 55 & $\begin{array}{l}\text { Lifestyle migrant, } \\
\text { Western Europe }\end{array}$ & Restaurant (2010) & $\begin{array}{l}\text { Spouse from } \\
\text { his country }\end{array}$ & Couple-led & Univ. degree & - \\
\hline
\end{tabular}

Source: own elaboration. 
Concerning the household situation, all of the participants were married at the time of the interview. Only Mehmet, a refugee from Asia, was married to a Norwegian woman, whereas the others were married to a woman from their country of origin. Ali had got married only a few months before the interview and had no children yet, whereas Jürgen had adult children at the time of the business start-up. Three of the others (Lars, Vladimir and Paul) had one young child at home at the time of the business start-up, and all of the participants except Jürgen and Ali had at least one (more) child during the first years after their business start-up. Most of the participants told that being a father was a rewarding experience, but several admitted that having children and running a business simultaneously was at times a time-consuming and exhausting combination.

\section{RESULTS AND DISCUSSION}

\section{Three Modes of Entry to Entrepreneurship}

A key finding that emerges from the analysis is the variation in the participants' reasons for becoming self-employed. In particular, three different modes of entry to entrepreneurship were identified: a) entrepreneurship as a means to live in a region of perceived attractiveness, b) entrepreneurship 'because I was asked to do it' and c) entrepreneurship as a preferred choice for men in satisfactory wage labour. These are variations of opportunity driven entrepreneurship. Below, I will present examples of these three modes of entry and thereafter discuss how the experiences of the interviewees are intrinsically embedded in the family and in the spatial context in which they live. However, I will first present a table offering an overview of how I have categorised the participants in this study.

Table 2. Overview of the participants and the mode of entry to entrepreneurship

\begin{tabular}{|l|l|}
\hline Mode of entry to entrepreneurship & Name/age/region of origin \\
\hline $\begin{array}{l}\text { Entrepreneurship as a means to live in a re- } \\
\text { gion of perceived attractiveness }\end{array}$ & $\begin{array}{l}\text { Jürgen (55), Western Europe } \\
\text { Ahmed (35), Asia }\end{array}$ \\
\hline $\begin{array}{l}\text { Entrepreneurship 'because I was asked to do } \\
\text { it' }\end{array}$ & Lars (35), Western Europe \\
& Erik (45), Western Europe \\
\hline $\begin{array}{l}\text { Entrepreneurship as a preferred choice for } \\
\text { men in satisfactory wage labour }\end{array}$ & $\begin{array}{l}\text { Ali (30), Asia } \\
\text { Vladimir (40), Russia } \\
\text { Julius (45), Asia } \\
\text { Mehmet (35), Asia }\end{array}$ \\
\hline
\end{tabular}

Source: own elaboration.

a) Entrepreneurship as a means to live in a region of perceived attractiveness. Some of the participants entered entrepreneurship as a way to live in Finnmark. Jürgen, a lifestyle migrant from Western Europe is an example of this strategy. He and his wife, Hilda, had spent their summer holidays in northern Norway for many years, and when their children became adults, Jürgen and Hilda wanted to move northwards. They applied for several jobs without success. One day, the couple decided that becoming self-employed would be their opportunity for settling in the north. Because Jürgen excelled at cooking and Hilda had some experience working in a café, they soon found that running a restaurant was the business idea that would suit 
them. They found suitable business premises for rent on the Internet, completed all the paperwork from their country of origin and moved to Finnmark, where they felt at home from the start.

Ahmed is another example of this type of entry mode. He is a refugee who was first assigned to Oslo, the capital region, after obtaining a residence permit. Ahmed indicated that he found work in a fast-food chain shortly after having completed the two-year compulsory introductory course for refugees. He enjoyed his work, obtained good references and soon secured permanent employment with more responsibilities. After a while, he encountered the opportunity to secure ownership of a retail store. Ahmed performed quite well, bought an apartment in Oslo and married a woman originating from the same country that he did. Two years later, he went to Finnmark on summer vacation to meet some friends and go river fishing there. He enjoyed his experience there and decided to sell the apartment in Oslo, quit his job and move northwards:

Ahmed: I was on vacation here in 2007 and I really liked what I saw. In addition, some of my friends lived here, and what's more, there was a pizza restaurant for sale here that I became interested in. So, I bought the pizzeria, sold everything in Oslo and settled in Finnmark. It was not only the business opportunity that made me move. I also like the natural environment and landscape here, both in summer and winter.

Researcher: Wow. That's so interesting. What do you like about the nature?

Ahmed: I love fishing. I do that a lot. Otherwise, I just find it easier to live here than in Oslo. It's close to the wild nature here; it's easy to have fun outdoors and relax. I prefer that to the stress in a city such as Oslo.

b) Entrepreneurship 'because I was asked to'. The second category emerging from the data analysis is entrepreneurship as a result of external requests. Lars, a lifestyle migrant from Western Europe, is an example of this type of entry. He originally came to Finnmark with his wife and their newborn baby as 'long-term tourists'. Before moving north, Lars had been running a business offering Chinese acupuncture treatments in his country of origin. When they decided to spend a year in the north, his wife was able to bring her maternity leave payment to Norway. Lars therefore temporarily closed his business. Their plan was to spend a year in Finnmark to have 'quality family time and enjoy the northern landscapes'. Lars explained that he used to take daily long walks in nature, feeling a calm that he had not felt before. One day, he said, he met a woman in the street who asked him to 'stop picking berries in the mountains all day and start working' because, as Lars explains, 'she had a bad hip and needed my help'. He added the following:

So I thought, why not? And that's how I started. Little by little. No rush, no panic. We still had the parental leave payment from home, and that was still enough to live on. However, one patient developed into two, and so on...

When Lars and his wife had spent a year in Finnmark, his firm had already performed quite well, and they were not yet ready to return to their country of origin. Thus, they decided to stay another year. His wife obtained an interesting job in the local labour market and their child entered kindergarten. The family grew, and they continued to stay there, until one day after several years of temporary decisions, they decided that it was 
time to make a permanent decision. Therefore, the couple decided to settle, bought a house and started a long renovation process.

Erik, who is also a lifestyle migrant, has a similar but somewhat different story. He came to Finnmark with his wife Vibeke ten years ago to do 'something exotic and different', primarily because Finnmark was the place where they both found interesting jobs (at the time, finding a job was not an easy task for architects who had recently graduated). Erik obtained employment in a private architectural firm in Finnmark, whereas Vibeke first obtained a job working for the municipality and then, some years later, began to work in the same firm as Erik. One day, the owner of the architectural firm revealed that she had been thinking about retiring, and she invited Erik and Vibeke to assume ownership of the firm. Because this idea was completely new for the couple, they needed time to reflect. However, several months later, they decided that taking over the company and developing it together was exactly what they wanted to do. Thus, they became entrepreneurs.

c) Entrepreneurship as a preferred choice for participants with satisfactory wage labour. The last and most common mode of entry identified in this study of male immigrant entrepreneurs is entrepreneurship as a preferred choice for participants with satisfactory wage labour. In this mode of entry, the participants reported that although they had held interesting and well-paid jobs that corresponded well to their formal and/or practical qualifications, they had, for various reasons, preferred to start their own businesses. The main motivations cited were that selfemployment would give them 'independence', implying that they would be their own bosses, earn money for themselves and hence obtain higher salaries than employees would and that they could determine their own working hours and schedule.

Independence. In the literature, the idea of being one's own boss to obtain independence is often cited as an important motivation for becoming self-employed, in particular by male entrepreneurs (Baycan-Levent, Masurel, \& Nijkamp, 2003; Brettell \& Alstatt, 2007; Zarrugh, 2007). In another study (Hilbrecht \& Lero, 2014) moreover, most participants identified independence as a significant motivational factor for business start-up, and several of the self-employed participants discussed experiencing a 'temporal flexibility' allowing them to organise their days in a way that permitted them to meet different needs in the family as well as in the business (for further elaboration of this theme, see Hilbrecht \& Lero, 2014, p. 31). This observation is also reported in this study: several of the men I interviewed explained that they chose to start a business to be their own bosses and hence to enjoy a certain 'flexibility' or 'independence'. Ali may serve as an example. He is a refugee who was running a restaurant offering both fast food and traditional Norwegian dishes. He started his business five years before the time of the interview, after having worked as an employee in another immigrant-led restaurant for several years. He stated that during the three to four first years of running his own business, he worked 11 hours per day seven days per week, and in addition, he did not take any holidays. 'However, things have changed', he explained, adding: 'now, I feel like a king.' He said that he currently had three employees to assist him, that he had bought an apartment and that he had purchased two cars. Moreover, he had recently got married and was waiting for family reunification with his wife. He explained that during the last couple of years, he had taught one of his employees everything about the 
business to ensure that his employee could run the restaurant when Ali was away. In fact, although Ali did not take holidays during his first years as a business owner, he certainly did take vacations around the time of the interview. Actually, he had met his future wife one year earlier. She lived in Asia. Hence, to meet her and her family and to marry her, Ali had spent several weeks there during the last few months, and he was soon returning to see her again. When I asked Ali to explain why he decided to start his own business despite having an interesting and fairly well-paid job in another restaurant, he answered as follows:

The best thing about being self-employed is that I can decide myself. I'Il explain. When it is quiet here in the morning, I can leave the restaurant to one of my employees and meet a friend over coffee in town and come back a little later. Or if I'm tired one day, I can call one of my employees and ask him to open the restaurant, and I'll come in a couple of hours later myself. When you're an employee, you can't do that sort of thing. You just have to be on time. You see?

Vladimir, who was running a small nature-based tourism firm, had a different view. He explained that the best aspect of being self-employed is that he can do his things in his own way and in his own pace:

I don't like industrial tourism. I want to work with small groups where you are in contact with everybody in the group, and I like the style where you just go out with the boat without any time schedule and people can just enjoy it. And it's not many companies in Norway that want to do this kind of business. Everybody wants to run after time schedules with every step being really organised. For me, that's industrial tourism. So after a while in that direction with [my former employer], I decided to start my own business.

\section{Family and Community Support}

Family embeddedness and the importance of spousal support. Whereas most of the female immigrant entrepreneurs in a broader study of rural immigrant entrepreneurship (Munkejord, 2015a, 2015b)clearly highlighted the importance of spousal support as a motivational or even decisive factor during the start-up phase, few of the male entrepreneurs mentioned this dimension when they discussed their experiences starting their businesses. Also, when I asked them about who had been significant persons in the startup phase, hardly anyone of the participants talked about their wives. But, when I explicitly inquired about the role played by their spouse, however, they told that they had received a lot of moral and even instrumental support from their partners during the startup and subsequent phases of business development. This male reluctance towards representing the spouse as a significant person in the establishment and development of the immigrant firm is well established in the literature coining the immigrant wife a 'silent contributor' of entrepreneurship processes (Dhaliwal, 1998).

In this study, however, the male informants did tell about the important role played by their wives when overtly inquired. Julius, a refugee running a massage therapy business, for instance, explained that he had needed a lot of support from his wife during the years. At times, he had felt quite lonely in the business, and the moral support from his wife had been of particularly great significance during such periods. Lars, who was currently working part time in his acupuncture institute as well, admitted that he and his 
family actually relied on the higher regular income of his wife and that without her wage, he would not have been able to work as little as he did and hence would not have been able to combine part-time work with their on-going home expansion project. Vladimir, who was in the early start-up phase of his nature-based tourism firm, also acknowledged that he had obtained not only moral support but also plenty of practical assistance from his wife during the start-up phase of his business. However, this acknowledgement came only after his wife, who was present in the living room during the interview, intervened; Vladimir had initially spoken little about the role of his wife during the business start-up phase. His wife hence indicated that she had in fact reduced her job to a $50 \%$ position during the last year to have more time available to assist her husband with paperwork, applications and strategies but that she planned to start prioritising her own career again soon.

In addition to providing moral and instrumental support, some of the women had even engaged in the business on equal terms. This equal engagement was found in the cases of Paul, Ahmed, Jürgen and Erik, who can be termed copreneurs owning and running the businesses together with their partners. For a discussion of the copreneur concept, see (Smith, 2000). Ahmed is an interesting example here. In fact, I had interviewed him for quite a while before I realised that he was running his restaurant not alone but together with his wife. This point had not been clear at the beginning of the interview because he repeatedly used the pronoun ' $I$ ' when explaining his path to Finnmark and into the restaurant business. When I understood that he actually owned and ran the place together with his wife and hence started asking questions about that collaboration, it was revealed that he and his wife had moved to Finnmark together and that it was actually his wife who had completed the paperwork and had obtained formal education in cooking, among other tasks. However, near the end of the interview, when I asked Ahmed whether he thought that he would have been able to start and run the restaurant without his wife, he laughed and admitted the following: 'It would have been difficult. I wouldn't have even wanted to. She is cleverer than me, you know!'

Spatial embeddedness. The most common theme in the start-up accounts from male immigrant entrepreneurs, in addition to family embeddedness, relates in various ways to what we may term spatial embeddedness. Erik may serve as an example. He is running an architectural firm together with his wife Vibeke, as mentioned above. Erik explained that in addition to drawing houses particularly adapted to a northern climate, they were also designing outdoor spaces, for instance, in relation to kindergartens and elderly homes. In addition, the couple had initiated several community projects in which they linked persons and activities related to northern cultures and landscapes by organising cultural events and concerts in a location being a former industrial area. The motivation for this engagement in what we can call place-making or place re-invention (Nyseth, 2009) was to 'give something back to the people here', as Erik phrased it. Another community project in which they had been involved focused on the northern lights as a resource for people in terms of outdoor experiences in Finnmark. Erik, Vibeke and their employees had worked on that initiative in several ways: giving education to municipal planners and advisors with regard to what type of artificial lightening should be used during the long and dark winter to prevent 'blinding' people as well as constructing 'gazing spots' where tourists and other interested people could enjoy the northern lights 
particularly well. Moreover, Erik and Vibeke were concerned about the value of knowing the northern culture to make houses and buildings that 'fit into the communities'. Erik stated as follows:

As architects, we think it is important to be close to people and cultures here. To know something about the north. In principle, you can sit anywhere designing buildings according to the guidelines of Norwegian law for housing and property, but in practice, it is of great value to be close to the people you are designing for, in terms of knowing both the local culture and not least the local climate.

Jürgen also discusses the importance of spatial embeddedness or even spatial belonging during the start-up phase of his business. When he and his wife took over the restaurant premises in Finnmark, they decided from day one that they did not want to enter the fast food market. Rather, they wanted to use local fresh fish and meat and primarily prepare and serve traditional dishes from the rural north in order to create a sense of pride and belonging among local people in their new home place. Jürgen explained that when starting his business, he purchased a Norwegian cookbook with traditional recipes and started experimenting with dishes inspired by that book. However, in the very beginning, the customers were not always entirely satisfied with the dished served. Hence, a regular guest, an elderly local woman, offered to help them: she went through the cookbook together with Jürgen and explained what she thought local people in the community would like and dislike. In addition, she brought old recipes from her family and guided Jürgen in how to make different local dishes. Other local people additionally contributed during the start-up phase in various ways. One neighbour, for instance, brought some of his own musical instruments and suggested that Jürgen and his wife could decorate the restaurant with those instruments and occasionally invite locals to perform music from time to time. The following-up to this idea was 'not without success', as Jürgen reported enthusiastically, stating that their café was in fact turning into an important meeting place, in particular for elderly local people in the community.

The stories of Erik and Jürgen show that male immigrants may feel embedded in their new region of settlement both in relation to people, places and cultures there. Immigrants, hence, may not only represent a much needed inflow of younger people in rural areas with a typically decreasing and ageing population. In addition, they create jobs for themselves and others, which may be very significant, both economically as well as symbolically in shaping a faith in the place and its future. In addition, several of the male interviewees in this study engage socially and culturally in various ways in their new home place, thus contributing to community building and place-making in the rural north.

\section{CONCLUSIONS}

Through the analysis of unique data, this study adds to the entrepreneurship literature in several ways. First, this study highlights the gendered experiences of male immigrant entrepreneurs. In fact, male entrepreneurs are often treated as neutral rather than gendered actors in the literature (Ahl \& Nelson, 2010). Moreover, this article identifies three distinct modes of entry into (rural immigrant) entrepreneurship and shows how they are embedded in the family and in the spatial context in which the entrepreneurs live. Regarding the family context, most of the participants highlighted the importance of 
spousal support in the start-up phase. In the beginning of the interview, however, the male participants tended to represent themselves according to the hegemonic stereotype of the independent and individualist entrepreneur. But when asked explicitly, they confirmed the important significance of spousal support and family embeddedness. In fact, some of the interviewees in this study have wives who had decided to join them in the business start-up as joint partners, whereas others had wives who had retained their jobs while also contributing to their husbands' start-up process by giving emotional and sometimes instrumental support. In addition, the start-up experiences of the interviewed immigrant men have been shaped by the spatial context in which they live: spatial dimensions were highlighted in different ways in relation to the start-up and development of the businesses in the study, and several of the participants of this study were motivated by the idea of contributing to local place development in the rural north. This theme is rarely, if ever, discussed in the immigrant entrepreneurship literature. Moreover, ethnicity should not be used as an overarching explanatory factor when trying to understand variations in immigrants' engagement in self-employment. Rather, differences should be analysed in terms of the entrepreneurs' gender and migration backgrounds, family context, human and social capital and various dimensions of the spatial embeddedness of the entrepreneur in the host context. Hence, the findings in this study suggest that our understanding of immigrant entrepreneurship would benefit from developing more nuanced theoretical models attentive to gender, household situation and geographical context.

Limitations and policy implications: The interpretative methodology has been valuable for identifying modes of entry to entrepreneurship and exploring how these modes are embedded in the family and spatial contexts of the participants in this study. The results respond to the call for contributions regarding the importance of including contextual factors in the analysis of the entrepreneurial start-up phase (Brush, de Bruin, \& Welter, 2009; Welter, 2011). However, this study has some limitations. First, this study has focused on a limited number of participants. Certainly, the entrepreneurial experience of male immigrants may be shaped in different ways in other contexts. It is important, therefore, not to generalise the findings to rural immigrant entrepreneurship in general. Further research is needed to examine other cases, larger samples and other contexts. In particular, whereas this article focuses on the qualitative and contextual aspects of the entrepreneurial start-up phase, future research is advised to use mixed methods to explore the qualitative and quantitative dimensions of the (rural) immigrant start-up phase.

This study notes that the modes of entry to rural immigrant entrepreneurship are diverse but are often related to the pursuit of an initial feeling of belonging in the new region of settlement. Hence, developing our knowledge of how to not only attract but also retain and increase the feeling of local belonging of immigrants and hence possibly increase their engagement in entrepreneurial processes may be relevant for many rural regions in the Western world, as also argued in (Munkejord, in press, 2017). Moreover, policies designed to directly encourage immigrant entrepreneurship must consider as their point of departure that variations within immigrant entrepreneurship experiences prompt the need for plural and contextualised policy initiatives. 


\section{REFERENCES}

Ahl, H. (2004). The scientific reproduction of gender inequality: a discourse analysis of research texts on women's entrepreneurship. Copenhagen: Copenhagen Business School.

Ahl, H. (2006). Why Research on Women Entrepreneurship Needs New Directions. Entrepreneurship, Theory \& Practice, 30(5), 595-621.

Ahl, H., \& Nelson, T. (2010). Moving forward: institutional perspectives on gender and entrepreneurship. International Journal of Gender and Entrepreneurship, 2(1), 5-9.

Aldrich, H. E., \& Cliff, J. E. (2003). The pervasive effects of family on entrepreneurship: toward a family embeddedness perspective. Journal of Business Venturing, 18, 573-596.

Aldrich, H. E., \& Waldinger, R. (1990). Ethnicity and entrepreneurship. Annu. Rev. Sociol., 16(1), 111-135.

Almor, T., \& Yeheskel, O. (2013). Footloose and fancy-free: sojourning entrepreneurs in China. Journal of Enterprising Communities: People and Places in the Global Economy, 7(4), 354-372.

Alsos, G. A., Carter, S., \& Ljunggren, E. (2014). Kinship and business: how entrepreneurial households facilitate business growth. Entrepreneurship and Regional Development, 26(1-2), 97-122.

Bagwell, S. (2008). Transnational family networks and ethnic minority business development. The case of Vietnamese nail-shops in the UK. International Journal of Entrepreneurial Behaviour \& Research, 14(6), 377-394.

Basu, A., \& Altinay, E. (2002). The interaction between Culture and Entrepreneurship in London's immigrant businesses. International Small Business Journal, 20(4), 371-393.

Bates, T., Jackson, W. E., \& Johnson, J. H. j. (2007). Introduction to the special issue on advancing research on minority entrepreneurship. Annals of American Academy of Political Science and Social Science, 316, 10-17.

Baycan-Levent, T., Masurel, E., \& Nijkamp, P. (2003). Diversity in entrepreneurship: ethnic and female roles in urban economic life. International Journal of Social Economics, 30(11), 11311161.

Brettell, C. B., \& Alstatt, K. E. (2007). The agency of immigrant entrepreneurs: biographies of the self-employed in ethnic and occupational niches of the urban labour market. Journal of Anthropological research, 63(3), 383-397.

Bruni, A., Gherardi, S., \& Poggio, B. (2004). Doing Gender, Doing Entrepreneurship: An Ethnographic Account of Intertwined Practices. Gender, Work and Organization, 11(4), 406-428.

Brush, C. G., de Bruin, A., \& Welter, F. (2009). A gender-aware framework for women's entrepreneurship. International Journal of Gender and Entrepreneurship, 1(1), 8-24.

Charmaz, K. (2005). Grounded Theory in the 21st century: Applications for Advancing Social Justice Studies. In N. K. Denzin \& Y. S. Lincoln (Eds.), The Sage Handbook of Qualitative Research (pp. 507-535). Thousand Oaks, London, New Dehli: Sage.

Charmaz, K. (2006). Constructing Grounded Theory. A Practical Guide Through Qualitative Analysis. London, Thousand Oaks: Sage.

Charmaz, K. (2009). Shifting the grounds. Constructivist Grounded Theory Methods. In J. M. Morse, P. N. Stern, J. Corbin, B. Bowers, K. Charmaz, \& A. E. Clarke (Eds.), Developing Grounded Theory. The second generation (pp. 127-147). Walnut Creek: Left Coast Press.

Collins, J., \& Low, A. (2010). Asian female immigrant entrepreneurs in small and medium-sized businesses in Australia. Entrepreneurship and Regional Development, 22(1), 97-111. 
Crockett, D. R. (2013). Immigrant entrepreneurs' selectivity: host market distance and oppotunity. Journal of Enterprising Communities: People and Places in the Global Economy, 7(3), 196-212.

Cullum, L. (2003). Narratives at Work. Women, Men, Unionization, and the Fashioning of Identities. Newfoundland: ISER Books, University of Newfoundland.

Danson, M., \& Jentch, B. (2009). The New Scottish Rural Labour Market: Processes of Inclusion and Exclusion. In B. Jentch \& M. Simard (Eds.), International Migration and Rural Areas. CrossNational Comparative Perspectives (pp. 127-150). Farnham, Burlington: Ashgate.

de Lima, P., \& Wright, S. (2009). Welcoming migrants. Migrant Labour in Rural Scotland. Social POlicy \& Society, 8(3), 391-404.

Dhaliwal, S. (1998). Silent contributors: Asian female entrepreneurs and women in business. Women's Studies International Forum, 21(5), 463-474.

Eddleston, K. A., \& Powell, G. N. (2012). Nurturing Entrepreneurs' Work-Family Balance: A Gendered Perspective. Entrepreneurship, Theory \& Practice, 36(3), 513-541.

Essers, C., Benschop, Y., \& Dooreward, H. (2010). Female ethnicity: Understanding Muslim Immigrant Businesswomen in The Netherlands. Gender, Work and Organization, 17(3), 320-339.

Evans, A. J. (2012). Ethnic enterprise governance: a public choice analysis of Liverpool's Chinatown. Journal of Enterprising Communities: People and Places in the Global Economy, 6(1), 28-38.

Fairlie, R. W., \& Meyer, B. D. (1996). Ethnic and Racial Self-employment Differences and Possible Explanations. The Journal of Human Resources, 31(4), 757-793.

Gartner, W. (1988). "Who Is an Entrepreneur?" Is the Wrong Question. American Journal of Small Business, 11-32.

Gerrard, S. (2005). Living with the Fish Quotas: Changing Gendered Practices? Tidsskrift for kjrrnnsforskning, 4, 34-49.

Gerrard, S. (2013). Mobilities, materialities, and masculinities: Interconnected mobility practices in Norwegian coastal fisheries. Norsk Geografisk Tidsskrift - Norwegian Journal of Geography, 67(5), 312-319.

Haavind, H. (1999). Analytiske retningslinjer ved empiriske studier av kjřnnede betydninger. In H. Haavind (Ed.), Kjřnn og fortolkende metode. Metodiske muligheter i kvalitativ forskning. Oslo: Gyldendal Akademisk.

Hilbrecht, M., \& Lero, D. S. (2014). Self-employment and family life: constructing work-life balance when you're 'always on'. Community, Work and Family, 17(1), 20-42.

Jennings, J. E., Breitkreuz, R. S., \& James, A. E. (2013). When Family Members are also Business Owners: Is Entrepreneurship Good for Families? Family Relations, 62(July), 472-489.

Jennings, J. E., \& Brush, C. (2013). Research on Women Entrepreneurs: Challenges to (and from) the Broader Entrepreneurship Literature? The Academy of Management Annals, 7(1), 663715.

Jennings, J. E., \& McDougald, M. S. (2007). Work-family interface experiences and coping strategies: Implications for entrepreneurship research and practice. Academy of Management Review, 32(3), 747-760.

Khosravi, S. (1999). Displacement and entrepreneurship: Iranian small businesses in Stockholm. Journal of Ethnic and Migration Studies, 25(3), 493-508.

Kloosterman, R. C., \& Rath, J. (2001). Immigrant entrepreneurs in advanced economies: Mixed embeddedness further explored. Journal of Ethnic and Migration Studies, 27(2), 189-201.

Lee, J. (1999). Retail Niche Domination Among African American, Jewish, and Korean Entrepreneurs. American Behavioral Scientist, 42(9), 1398-1416. 
Mora, M. T., \& Dávila, A. (2005). Ethnic group size, linguistic isolation, and immigrant entrepreurship in the USA. Entrepreneurship and Regional Development, 17(5), 389-404.

Munkejord, M. C. (2015a). Local and transnational networking among female immigrant entrepreneurs in peripheral rural contexts: perspectives on Russians in Finnmark, Norway. European Urban and Regional Studies, $x(x), 1-14$, DOI: 10.1177/0969776415587122.

Munkejord, M. C. (2015b). Rural immigrant entrepreneurship: An arena for new constructions of gender in Finnmark, northernmost Norway. In H. P. Nielsen \& S. T. Faber (Eds.), Global Confluences and Local Particularities. Remapping Gender, Place and Mobility in Nordic Peripheries (pp. 159-173). London: Ashgate.

Munkejord, M. C. (in press, 2017). Immigrant Entrepreneurship Contextualised: Becoming a female migrant entrepreneur in Rural Norway. Journal of Enterprising Communities: People and Places in the Global Economy, 11(4), $x-x$.

Nyseth, T. (2009). Place Reinvention at the Northern Rim. In T. Nyseth \& A. Viken (Eds.), Place Reinvention. Northern Perspectives. (pp. 1-14). Aldershot: Farnham.

O'Reilly, K., \& Benson, M. (2009). Lifestyle Migration: Escaping to the Good Life? In M. Benson \& K. O'Reilly (Eds.), Lifestyle Migration. Expectations, Aspirations and Experiences. (pp. 1-14). Farnham, Burlington: Ashgate.

Phizacklea, A., \& Ram, M. (1996). Being your own boss: ethnic minority entrepreneurs in comparative perspective. Work, Employment \& Society, 10(2), 319-339.

Portes, A., \& Zhou, M. (1996). Self-employment and the Earnings of Immigrants. American Sociological Review, 61(2), 219-230.

Ram, M., \& Jones, T. (2008). Ethnic minority businesses in the UK: An overview. Migracőes, 3, 6171.

Rogoff, E. G., \& Heck, R. K. Z. (2003). Evolving research in entrepreneurship and family business: Recognizong family as the oxygen that feeds the fire of entrepreneurship. Journal of Business Venturing, 18(5), 559-566.

Shaw, E. (2006). Small Firm Networking: An Insight into Contents and Motivating Fasctors. International Small Business Journal, 24(5), 5-29.

Shinnar, R. S., \& Young, C. A. (2008). Hispanic immigrant entrepreneurs in the Las Vegas metropoli$\tan$ area: motivations for entry and outcomes of self-employment. Journal of Small Business Management, 46(2), 242-262.

Simard, M., \& Jentch, B. (2009). Introduction: Key Issues in Contemporary Rural Immigration. In B. Jentsch \& M. Simard (Eds.), International Migration and Rural Areas. Cross-National Comparative Perspectives (pp. 1-16). Farnham, Burlington: Ashgate.

Smith, C. R. (2000). Managing work and family in small "copreneurial" business: an Australian study. Women in Management Review, 5/6, 283-289.

Stephens, S. (2013). Building and entrepreneurial network: the experiences of immigrant entrepreneurs. Journal of Enterprising Communities: People and Places in the Global Economy, 7(3), 233-244.

Srnndergaard, D. M. (1999). Destabiliserende diskursanalyse: veje ind i poststrukturalistisk inspirert empirisk forskning. In H. Haavind (Ed.), Kjřnn og fortolkende metode. Metodiske muligheter $i$ kvalitativ forskning. (pp. 60-104). Oslo: Gyldendal Akademisk.

Sřndergaard, D. M. (2002). Poststructuralist approaches to empirical analysis. Qualitative studies in Education, 15(2), 187-204.

Teixeira, C. (1998). Cultural resources and ethnic entrepreneurship: A case study of the Portugese real estate industry in Toronto. Canadian Geographer, 42(3), 267-281. 
Terjesen, S., \& Elam, A. (2009). Transnational Entrepreneurs' Venture Internationalization Strategies: A Practice Theory Approach. Entrepreneurship, Theory \& Practice, 33(5), 1093-1120.

Turkina, E., \& Thai, M. T. T. (2013). Social capital, networks, trust and immigrant entrepreneurshp: a cross-country analysis. Journal of Enterprising Communities: People and Places in the Global Economy, 7(2), 108-124.

Waldinger, R. (1994). The making of an immigrant niche. International Migration Review, 28(1), 330.

Welter, F. (2011). Contextualizing Entrepreneurship - Conceptual Challenges and Ways Forward. Entrepreneurship, Theory \& Practice, 35(1), 165-184.

Zarrugh, L. H. (2007). From workers to owners: Latino entrepreneurs in Harrisonburg, Virginia. Human Organization, 66(3), 240-248.

\title{
Author
}

\section{Mai Camilla Munkejord}

Senior Researcher at Uni Rokkan Centre, Bergen, Norway; Associate Professor at Department of Tourism and Northern Studies, UiT The Arctic University of Norway, Norway

\author{
Correspondence to: \\ Mai Camilla Munkejord \\ Uni Research Rokkan Centre, Nygårdsgaten 5, \\ N-5015 Bergen, Norway \\ $+4747310602$ \\ mai.munkejord@uni.no
}

\section{Acknowledgementsand Financial Disclosure}

This study is part of a research project headed by professor Einar Rasmussen, UiN, entitled "Border-crossing business activity in the Barents Region: Understanding the drivers and barriers for transnational entrepreneurship" (2012-2016). This project was financed by the Norwegian Research Council, grant number 212361 as well as by the former Finnmark University College, Norway.

Many thanks to the reviewers and the editor for fruitful comments, and thanks also for inspiring comments from participants at the RENT 2014 conference in Luxembourg where an earlier draft of this paper was presented.

\section{Copyright and License}

This article is published under the terms of the Creative Commons Attribution - NonCommercial - NoDerivs (CC BY-NC-ND 3.0) License http://creativecommons.org/licenses/by-nc-nd/3.0/ 